\title{
ТЕРМОГЕЛИОКС - ПРИНЦИПИАЛЬНО НОВАЯ МЕДИЦИНСКАЯ ТЕХНОЛОГИЯ
}

\author{
С.Д. Варфоломеев \\ Институт биохимической физики им. Н.М.Эмануэля РАН, \\ 119334, Россия, Москва, ул.Косыгина, 4. \\ Химический факультет Московского государственного университета \\ имени М.В.Ломоносова, 119991, Россия, Москва, Ленинские горы, дом 1, стр. 3. \\ DOI: 10.19163/MedChemRussia2021-2021-11 \\ E-mail: sdvarf@sky.chph.ras.ru
}

Принципы и базовые достижения. Использование дыхательной смеси кислорода и гелия в качестве медицинской и физиотерапевтической процедуры за последнее пятилетие прошло всестороннюю проверку и широкое терапевтическое применение. Физические свойства гелий-кислородной смеси обеспечивают её диффузионную подвижность, теплоемкость и проникающую способность, что делает облегченным транспорт кислорода во все органы и ткани человека. Принципиально важным является существенное улучшение транспортных возможностей микрокапиллярной системы кровообращения и повышение микроциркуляции крови во всех органах и тканях, включая мозг. Термогелиокс (смесь гелия и кислорода, подогретая до $45-100^{\circ} \mathrm{C}$ ) прошла апробацию и клиническое применение в разнообразных областях современной медицины. Создан современный ряд аппаратов (А.А.Панин). Наличие аппаратурной базы обеспечило возможность проведения большого комплекса клинических применений, включая хронические респираторные заболевания (акад. А.Г.Чучалин), неврологические поражения инсультного типа, патологии беременности, урологию, спортивную медицину и спорт высших достижений.

Термогелиокс - стимулятор иммунного ответа, лечение острой коронавирусной инфекции. Принципиально важные результаты получены по лечению острых вирусных респираторных заболеваний с использованием высокотемпературного термогелиокса (НИИ скорой помощи им.Н.В.Склифосовского, проф. С.В.Журавель). Продемонстрировано новое медико-биологическое явление - термовакцинация - стимулирование синтеза специфических антител IgG. Механизм термовакцинации включает термодеструкцию вируса (на 2-3 день применения организм освобождается от вирусных частиц) и наработку антител на вирусные белки. Разработанный подход позволяет провести ускоренную вакцинацию пациентов с первыми признаками вирусного поражения.

\section{Литература}

[1] Sergey D. Varfolomeev, Alexander A. Panin et al., Chemico-Biological Interactions, 2020, 329, 109209, Chemical kinetics of the development of coronaviral infection in the human body:

Critical conditions, toxicity mechanisms, «thermoheliox», and «thermovaccination».

[2] Sergey D. Varfolomeev, Alexander A. Panin et al., Chemico-Biological Interactions, 2021, 334, 109339, Thermovaccination - thermohelox as a stimulator of the immune response.

Kinetics of the synthesis of antibodies and C-reactive protein in coronavirus infection.

[3] Л.В.Шогенова, С.Д.Варфоломеев и др., Пульмонология, 2020, 30(5), 533-543. Влияние термической гелий-кислородной смеси на вирусную нагрузку при COVID-19. 